\title{
Nowe stanowiska rzadkich gatunków roślin naczyniowych torfowisk mszarnych na terenie Tatrzańskiego Parku Narodowego i w jego sąsiedztwie
}

\author{
Anna Maria Ociepa, Anna Koczur i Antoni Zięba
}

\begin{abstract}
Ociepa, A. M., Koczur, A. AND ZiĘBA, A. 2020. New locatities of rare peat bog species in Tatra National Park and its adjacent area (Poland). Fragmenta Floristica et Geobotanica Polonica 27(2): 395-408. Kraków. e-ISSN 2449-8890, ISSN 1640-629X.

ABSTRACT: The paper presents new localities of rare and threatened vascular plant species of the Tatra Mountains and Sub-Tatra Depression (Southern Poland). The analysed species occur on peat bogs. Data were collected during several field studies carried out between 2010 and 2019. We described 40 localities of 10 taxa: Andromeda polifolia, Carex cespitosa, Carex limosa, Carex pauciflora, Comarum palustre, Drosera rotundifolia, Ledum palustre, Listera cordata, Oxycoccus microcarpus and Oxycoccus palustris.
\end{abstract}

KEY WORDS: new localities, peat bog plants, rare species, Sub-Tatra Depression, Tatra Mountains, threatened species

A. M. Ociepa (autor korespondencyjny), FUP Kościelisko, skrytka nr 17, 34-511 Kościelisko, Polska; e-mail: amociepa@interia.pl

A. Koczur, ul. Kmietowicza 1/4, 30-092 Kraków,Polska; e-mail: koczur.anna@yahoo.com

A. Zięba, Tatrzański Park Narodowy, ul. Kuźnice 1, 34-500 Zakopane, Polska; e-mail: azieba@ tpn.pl

\section{WSTEP}

Na terenie Tatrzańskiego Parku Narodowego i w jego bezpośrednim sąsiedztwie torfowiska mszarne zajmują niewielkie powierzchnie (kilka hektarów - MiREK i in. 2013b), podobnie jest na terenach przyległych (Bruzdy Podtatrzańskiej). Rozwinęły się głównie między wałami moren bocznych i zboczami dolin oraz między wałami moren recesyjnych, w drugim przypadku przede wszystkim w obrębie zagłębień wytopiskowych (DERKACZ 2006; ŁAJCZAK 2014). Zarówno powierzchnia torfowisk, jak i miąższość pokładów torfu są bardzo zróżnicowane. Większość z nich to obiekty małe i silnie rozproszone, w skrajnych przypadkach zajmujące zaledwie kilka metrów kwadratowych. Również miąższość torfu bywa niewielka i w większości przypadków waha się od 30 do $150 \mathrm{~cm}$. Siedliskami roślinności torfowiskowej są też miejsca formalnie niezaliczane już do torfowisk, charakteryzujące się skrajnie płytkim pokładem torfu - zaledwie 10-30 cm. Wśród torfowisk mszarnych przeważają obiekty o zasilaniu topogenicznym oraz mieszanym, jedynie nieliczne 
charakteryzuje zasilanie typowo ombrogeniczne. Niektóre obiekty łączą w sobie wszystkie trzy typy zasilania. Torfowiska alkaliczne, o soligenicznym typie zasilania, na terenie TPN występują jeszcze rzadziej niż torfowiska mszarne, natomiast ich liczba znacznie wzrasta tuż za jego granicą, w obrębie Bruzdy Podtatrzańskiej. Torfowiska te, podobnie jak płaty typowo ombrogenicznych torfowisk położonych na grzbietach i stokach górskich, nie zostały uwzględnione, gdyż nie znaleziono tu nowych stanowisk torfowiskowych roślin naczyniowych. Tereny TPN, na których znajdują się największe skupienia torfowisk od 9 maja 2018 r. znalazły się na liście obszarów wodno-błotnych o międzynarodowym znaczeniu, czyli tzw. obszarów Ramsar, jako Torfowiska Tatrzańskiego Parku Narodowego nr 2341 na liście Ramsar (RAMSAR Sites INFORMATION SERVICE: https://rsis.ramsar. org/ris/2341; KAUZAL \& ZiĘBA 2018). Pomimo że torfowiska i płytkie zatorfienia zajmują niewielki procent powierzchni TPN, są jednak bardzo interesujące pod względem przyrodniczym, a ich flora obfituje w gatunki rzadkie i zagrożone zarówno na terenie Karpat, jak i całego kraju. Szata roślinna Tatr jest badana od XIX w., jednak wciąż istnieją luki w jej poznaniu. Dotyczą one między innymi torfowisk i świerkowych borów bagiennych. Badania mające na celu uzupełnienie stanu wiedzy na temat powyższych siedlisk były prowadzone w latach 2010-2020. W czasie ich trwania odnaleziono szereg nowych stanowisk gatunków torfowiskowych oraz potwierdzono wiele z wcześniej opisywanych.

Celem pracy jest prezentacja nowych, dotychczas niepublikowanych stanowisk wybranych gatunków.

\section{UWAGI METODYCZNE}

Prezentowane dane pochodzą z badań torfowisk Tatr i Rowu Podtatrzańskiego (Bruzdy Podtatrzańskiej) z lat 2010-2014 (Anna Koczur) oraz borów bagiennych Tatrzańskiego Parku Narodowego z lat 2019-2020 (Anna Koczur, Anna Maria Ociepa, Antoni Zięba). Uwzględniono taksony ujęte w Polskiej czerwonej księdze roślin (KAźMIERCZAKOwa i in. 2014), Czerwonej księdze Karpat Polskich (MiReK \& PięKoś-MiRKowa 2008) i Polskiej czerwonej liście paprotników i roślin kwiatowych (KaźmierCZaKowa i in. 2016). Dodano też jeden gatunek nie podawany do tej pory z Tatrzańskiego Parku Narodowego i nie wymieniony w Operacie ochrony roślin naczyniowych (MIREK i in. 2013a), sporządzonym na potrzeby przygotowania projektu Planu Ochrony TPN. Współrzędne geograficzne stanowisk zostały przekazane do wewnętrznej geobazy Tatrzańskiego Parku Narodowego.

Wykaz taksonów przygotowano według schematu: nazwa gatunkowa, kategoria zagrożenia według Polskiej czerwonej księgi roślin, kategoria zagrożenia według Czerwonej księgi Karpat Polskich (w nawiasie), kategoria zagrożenia według Polskiej czerwonej listy paprotników i roślin kwiatowych (w nawiasie kwadratowym), rodzaj ochrony (według rozporządzenia Ministra Środowiska z dnia 9 października 2014 r. w sprawie ochrony gatunkowej roślin - Dz.U. poz. 1409), informacja dla jakiej jednostki fitosocjologicznej dany gatunek jest charakterystyczny lub wyróżniający, opis znanych dotychczas stanowisk (z zaznaczeniem ich potwierdzenia $\mathrm{w}$ trakcie badań), a następnie opisano nowe stanowiska podając: nr kwadratu ATPOL (ZAJĄC 1978; ZAJĄC \& ZAJĄC 2001; KOMSTA 2016) wraz z oznaczeniem kwadratu o boku $1 \mathrm{~km}$ (analogicznie do numeracji ATPOL), nazwę 
topograficzną stanowiska, jednostkę geograficzną (Tatry lub Bruzda Podtatrzańska), informację o położeniu stanowiska na terenie obszaru Ramsar, wysokość nad poziom morza, zajmowane siedlisko, liczebność, datę obserwacji, inicjały autora/autorów obserwacji. Przy stanowiskach zlokalizowanych poza terenem Tatrzańskiego Parku Narodowego umieszczono odpowiednią adnotację, zapisano również informację, gdy stanowisko to jest maksimum wysokościowym gatunku w Polsce. Ponieważ badania torfowisk i borów bagiennych nie zostały jeszcze zakończone, informacje o zajmowanym siedlisku podano ogólnie, bez wyróżniania zespołów i zbiorowisk roślinnych. Nazwy gatunków przyjęto za MIRKIEM i in. (2002), natomiast granicę Tatr i nazwy jednostek geograficznych za BALONEM i in. (2015) i SOLONEM $\mathrm{i}$ in. (2018).

Zastosowane skróty i symbole: BP - Bruzda Podtatrzańska, T - Tatry; R1 - obszar Ramsar nr 2341 Torfowiska Tatrzańskiego Parku Narodowego, R2 - obszar Ramsar nr 2340 Polodowcowe Stawy Tatrzańskiego Parku Narodowego; AK - Anna Koczur, AMO - Anna Maria Ociepa, AZ - Antoni Zięba, BB - Bogusław Binkiewicz, PK - Paweł Kauzal.

\section{WYKAZ GATUNKÓW}

Andromeda polifolia - (VU), ochrona częściowa, gatunek charakterystyczny dla rzędu Sphagnetalia magellanici (MATUSZKIEWICZ 2008). Z Bruzdy Podtatrzańskiej gatunek nie był podawany, natomiast z polskiej części Tatr znane są dwa stanowiska: Toporowy Staw Wyżni (KotUla 1889-1890; RADwańsKAPARYSKa 1975; PięKoś-Mirkowa 1982; KorzeniaK i in. 2008a - potwierdzone 29.08.2019 r., AK, AMO) i Wielka Pańszczycka Młaka (Pacyna 1966; OBIDowicz 1975 - potwierdzone 07.07.2010 r., AK i 14.09.2019 r., AMO).

1. EG5056 Torfowisko na zach. od Pańszczyckiego Potoku, T, R1, ok. 1327 m, na torfowisku wysokim i w świerczynie porastającej torfowisko, dość licznie, 21.09.2019 r., AMO.

2. EG5046 Butorów, T, R1, ok. 1280 m, na torfowisku wysokim, dość licznie, 16.10.2019 r., AMO, AZ.

Carex cespitosa - gatunek nie jest ujęty w Czerwonych księgach, polskiej i karpackiej, ani na ogólnopolskiej Czerwonej liście, natomiast pojawia się na regionalnych czerwonych listach: województwa śląskiego z kategorią DD (PARUSEL \& URBISZ 2012), województwa opolskiego z kategorią EN (NowAK i in. 2008) i Polski środkowej (JAKUBOwSKA-GABARA \& KUCHARSKI 1999). W Europie w 8 na 19 krajów, w których występuje, uważany jest za gatunek zagrożony lub bliski zagrożenia (JIMÉNEZ-MEJías i in. 2014). MATUSZKIEWICZ (2008) podaje ten gatunek jako charakterystyczny dla zespołu Caricetum cespitosae ze związku Calthion. Rośnie głównie na torfowiskach oraz wilgotnych i mokrych zatorfionych łąkach. W Atlasie rozmieszczenia roślin naczyniowych w Polsce (ZAJĄC \& ZAJĄC 2001) brak stanowisk z terenu Karpat, jednak gatunek ten występuje stosunkowo często na obrzeżach torfowisk wysokich w Bieszczadach (Koczur 2013) i Kotlinie Orawsko-Nowotarskiej (Koczur, mat. npbl.). MireK \& PIĘKOŚ-MirkowA (1989) podają go z Bruzdy Podtatrzańskiej z Polany Biały Potok.

1. DG5930 Polana Molkówka, BP, poza TPN, ok. 959 m, torfowisko przejściowe, łąka na torfie, licznie, 20.07.2011 r., AK.

2. EG6009 Dolina Rybiego Potoku, T, ok. 1315 m; torfowisko w pobliżu polany Włosienica, pod Granią Żabiego, niezbyt licznie, 27.09.2019 r., AMO; pierwsze stanowisko w Tatrzańskim Parku Narodowym, maksimum wysokościowe w Polsce.

Carex limosa - (EN), [NT], gatunek charakterystyczny dla rzędu Scheuchzerietalia palustris i zespołu Caricetum limosae (Matuszkiewicz 2008). Z Bruzdy Podtatrzańskiej znany z Polany Biały Potok (Mirek \& PięKoś-Mirkowa 1989; Koczur i in. 2008c - potwierdzone 02.07.2010 r., AK) i Bystrego (REHMAN 1868), a z Tatr z Toporowego Stawu Wyżniego (KotUla 1889-1890; STECKI 1922; PiĘKoŚ-MiRKOWA 1982; KocZUR i in. 2008c - ostatnie potwierdzenia: 03.07.2010 r., AK i 29.08.2019 r., AK, AMO). 
1. EG5046 Wyżnia Pańszczycka Młaka, T, R1, ok. 1309 m, w zbiorowisku z dominacją Carex rostrata, nielicznie, 07.07.2010 r., AK; 20.08.2016 r., PK.

2. DG5979 Dolina Kondratowa, T, ok. 1398 m, na torfowisku przejściowym z elementami wysokiego, bardzo licznie, 10.09.2019 r., AMO; jest to maksimum wysokościowe w Polsce.

Carex pauciflora - EN, (EN), [EN], Gatunek charakterystyczny rzędu Sphagnetalia magellanici i związku Eriophoro-Trichophoretum caespitosi (MATUSZKIEWICZ 2008). Podawany z Bruzdy Podtatrzańskiej z Polany Biały Potok (Mirek \& PięKoś-Mirkowa 1989; Koczur i in. 2008d - potwierdzono 02.07.2010 r., AK) i Molkówki, gdzie ostatni raz był notowany przez KotULE (1889-1890). W Tatrach gatunek był podawany z podnóża Ornaku (FrITZE \& ILSE 1870) z Wyżniej Doliny Chochołowskiej (KocZUR i in. 2008c - potwierdzone 30.07.2020 r., AZ), Ostrego Wierchu (KotUla 1889-1890) i Toporowego Stawu Wyżniego (KotUla 1889-1890; Oвidowicz 1975; Koczur i in. 2008c - ostatnie potwierdzenia 03.07.2010 r., AK; 29.08.2019 r. AK, AMO), Wielkiej Pańszczyckiej Młaki (PACYNA 1966; OBidowicz 1975; KocZUR i in. 2008d - ostatnie potwierdzenia 07.07.2010 r., AK; 14.09.2019 r. AMO), Małej Pańszczyckiej Młaki (PACYNA 1966; OBIDOWICZ 1975; KoCZUR i in. 2008d - ostatnie potwierdzenia 16.07.2011 r., AK; 14.09.2019 r., AMO), kilku miejsc w Dolinie Pięciu Stawów Polskich: z okolic Wielkiego Stawu, Wolarczysk, na północ od Czarnego Stawu i Starego Solniska (BALCERKIEWICZ 1984 - 30.07.2012 r. potwierdzono stanowiska na północ od Czarnego Stawu, BB, a 06.08.2013 r. w rejonie Starego Solniska, AK) i okolic Morskiego Oka (HAUSNeCht - W: KotUla 1889-1890; PAWŁowski i in. 1928).

1. EG5057 Waksmundzka Młaka, T, R1, ok. $1366 \mathrm{~m}$, pojedynczo w większych przerwach między krzewami kosówki, w całym liczącym ok. 0,2 ha płacie kosodrzewiny na torfie, 07.07.2010 r., AK; 22.09.2019 r., AMO.

2. EG5046 Wyżnia Pańszczycka Młaka, T, R1, ok. 1309, 1354 m, torfowisko przejściowe z elementami wysokiego, dość licznie, 07.07.2010 r., AK, 22.09.2019 r., AMO.

3. EG5057 Rówień Waksmundzka, T, R1, ok. 1409 m, na torfowisku wysokim, pojedynczo, 16.07.2011 r., AK.

4. DG5993 Dolina Tomanowa, przy szlaku nad Smreczyński Staw, T, R1, 1174-1180 m, na torfowisku wysokim, dość licznie, 02.08.2012 r., AK; 31.08.2019 r., AMO.

5. EG5082 Pod Kotlinowym Stawkiem, T, R2, ok. 1677 m, w płatach torfowiska przejściowego, pojedynczo, 14.07.2014 r., AK.

6. EG5056 Torfowisko na zach. od Pańszczyckiego Potoku, T, R1, ok. 1327 m, na torfowisku wysokim, licznie, 21.09.2019 r., AMO.

Comarum palustre - (VU), gatunek charakterystyczny dla klasy Scheuchzerio-Caricetea nigrae i związku Caricion lasiocarpae (MatuszKiewicz 2008). Podawany z Bruzdy Podtatrzańskiej z Molkówki (PięKOŚ-Mirkowa \& MireK 1978; KorzeniaK i in. 2008b - potwierdzono 20.07.2011 r. AK) i Polany Biały Potok (KoRZENIAK i in. 2008b - potwierdzono 02.07.2010 r., AK), z Tatr z Toporowego Stawu Wyżniego (Kotula 1889-1890; PięKoŚ-Mirkowa 1982; KorZEniaK i in. 2008b - potwierdzono 03.07.2010 r., AK).

1. EG5027 Wawrzeczkowa Cyrhla, BP, ok. 950 m, kwaśna młaka, nielicznie, 09.07.2013 r., AK.

Drosera rotundifolia - [NT], ochrona ścisła, gatunek charakterystyczny dla klasy Oxycocco-Sphagnetea (MatusZKIEWICZ 2008). Podawany z Bruzdy Podtatrzańskiej z Molkówki (KotUla 1889-1890; RaCiBorsKi 1911; PaWŁowsKi 1956; PaWŁowsKi i in. 1970, potwierdzenie 20.07.2010 r., AK; MireK 2016), Polany Biały Potok (PawŁowski 1956; MireK \& PięKoś-Mirkowa 1989, potwierdzenie 02.07.2010 r. AK, MireK 2016), a także: z Zakopanego, Olczy, Weszkówki i Wojtkówki, nad Suchą Wodą, nad Kośnymi Hamrami między potokiem Chowańcówką i Cichą Wodą (PAwŁowski 1956; PAwŁowski i in. 1970) i Kościeliska - Rysulówki (HAJEK 1999). Ostatnio potwierdzono stanowiska w rejonie Weszkówki (Wyskówki) - ok. 896 m, na kwaśnej młace, pojedynczo, 12.09.2019 r., AK i Bafiówek, które jest prawdopodobnie tożsame z Wojtkówką - ok. 855 m n.p.m., rozległa młaka, pojedynczo 18.09.2019 r., AK, AMO. Z Tatr podawany ze Smreczyńskiego Stawu (PAwŁowski 1956), Toporowego Stawu Wyżniego (KotUla 1889-1890, RADWAŃSKA-PARYSKA 1950 - ostatnie potwierdzenia 03.07.2010 r., AK; 18.09.2019 r., AK, AMO) oraz spod Przysłopu Waksmundzkiego (PAwŁowski 1956).

1. EG5012 Bory Jaszczurowskie, BP, poza TPN, ok. 893 m, na kwaśnej młace, dość licznie, 01.07.2010 r., AK. 
2. EG5046 Wyżnia Pańszczycka Młaka, T, R1, ok. 1354 m, torfowisko przejściowe, nielicznie, 07.07.2010 r., AK, 13.09.2020 r., AMO.

3. DG5993 Dolina Tomanowa, przy szlaku nad Smreczyński Staw, T, R1, ok. 1178 m, na torfowisku wysokim, licznie, 01.09.2019 r., AMO.

4. EG5014 między Kiełbasówką a Wyskówkami, BP, ok. 950 m, na torfowisku wysokim, licznie, 05.08.2020 r., AMO.

Ledum palustre - (VU), ochrona częściowa, gatunek charakterystyczny związku Vaccinio uliginosiPinetum sylvestris, wyróżniający dla rzędu Cladonio-Vaccinietalia, zespołu Ledo-Sphagnetum magellanici i związku Oxycocco-Empetrion hermaphroditi (MatuszKIEwicz 2008). Podawany z Bruzdy Podtatrzańskiej z Molkówki (PięKoś-Mirkowa \& Mirek 1978; Koczur i in. 2008a; MireK 2016) i Wyskówek (MireK 1989, 2016), z Tatr z Toporowego Stawu Niżniego (RADWAŃSKA-PARYSKa 1975, potem nie odnaleziony - KoCZUR i in. 2008a), Toporowego Stawu Wyżniego (KotUla 1889-1890; RADWAŃSKA-PARYSKA 1975; PięKoś-Mirkowa 1982; Koczur i in. 2008a - ostatnie potwierdzenie 29.08.2019 r. AK, AMO), Kondrackich Rówienek (KocZUR i in. 2008a) i poniżej przeł. Iwaniackiej (RADWAŃSKA-PARYSKA 1950).

1. EG5045 Kotlinowy Wierch, T, R1, ok. 1285 m, w zaroślach kosodrzewiny na torfie, kilka osobników do $50 \mathrm{~cm}$ wysokości, 24.08.2019 r., AMO.

Listera cordata - [VU], ochrona ścisła, gatunek charakterystyczny dla zespołu Empetro nigri-Pinetum, związku Piceion abietis, zespołu Sphagno girgensohnii-Piceetum (MATUSZKIEwICZ 2008). W Tatrach notowany był na około 58 stanowiskach, z których zdecydowanej większości (ponad 80\%) nie udało się w ostatnich latach potwierdzić (BINKIEWICZ i in. 2017). Prawie wszystkie stanowiska znajdowały się w obrębie borów świerkowych, jednak tylko niewielka część z nich to typowe siedliska natorfowe (głównie Bazzanio-Piceetum), większość położona była na siedliskach mineralnych, głównie w Plagiothecio-Piceetum i Abieti-Piceetum (m.in.: SzAFER i in. 1927; PięKoś 1968; Mirek \& PięKoś-Mirkowa 1995; BinkiewICZ i in. 2017). Tylko nieliczne stanowiska odnajdowane były w zaroślach kosodrzewiny (SzAFER i in. 1927). Wszystkie znane stanowiska z Tatrzańskiego Parku Narodowego i jego obrzeży zostały przedstawione w pracy BINKIEWICZA i in. (2017), poniżej podano tylko nowe stanowiska i te, których wymienionym autorom nie udało się potwierdzić.

1. EG6018 Żabi Staw, T, R2, prawdopodobnie tożsame ze stanowiskiem Morskie Oko, ok. 1384 m n.p.m., podanym przez KотULE (1889-1890), ok. 1390 m, w natorfowej świerczynie, pojedynczo, 31.08.2019 r., AK.

2. DG5993 Dolina Tomanowa, przy szlaku nad Smreczyński Staw, T, R1, ok. 1173 m i ok. 150 m dalej, $1181 \mathrm{~m}$, w podmokłej świerczynie górskiej, pojedynczo, 01.09.2019 r., AMO.

3. DG5993 Dolina Tomanowa przy szlaku nad Smreczyński Staw T, R1, ok. 1179 m, w zaroślach kosodrzewiny na torfie, 04.09.2019 r., AMO.

4. EG5056 koło torfowiska na zach. od Pańszczyckiego Potoku, T, R1, ok. 1322 m, w natorfowej świerczynie, pojedynczo, 25.09.2019 r., AMO.

Oxycoccus microcarpus - (EN), [DD], gatunek charakterystyczny dla związku Oxycocco-Empetrion hermaphroditi (MATUszKiewicz 2008). Podawany z Bruzdy Podtatrzańskiej z Borów Jaszczurowskich (RADWAŃSKA-PARYSKA 1975 - później nie potwierdzone - KocZUR \& KorZENIAK 2008), Polany Biały Potok (Mirek \& PięKoś-Mirkowa 1989) z Tatr z Wielkiej Pańszczyckiej Młaki (Pacyna 1966 - potwierdzono w 07.07.2010 r., AK) i Polany Waksmundzkiej (RADWAŃSKA-PARYSKA 1975; PIĘKOŚMirKowA 1982).

1. DG5993 Dolina Tomanowa, przy szlaku nad Smreczyński Staw, T, R1, ok. 1174 m, na torfowisku wysokim, pojedynczo, 02.08.2012 r., AK;

2. EG5034 Toporowy Staw Wyżni, T, R1, ok. 1131 m, na obrzeżu torfowiska, nielicznie, 29.08.2019 r. AK, AMO.

Oxycoccus palustris Pers. - (VU), gatunek charakterystyczny dla rzędu Sphagnetalia magellanici (MatusZKiEwicz 2008). Z Bruzdy Podtatrzańskiej podawany z Molkówki (KotUla 1889-1890; KoczUR i in. 2008e, potwierdzenie 27.07.2011 r., AK, MireK 2016), Polany Biały Potok (MireK \& PięKoś-MirKOwa 1989; Koczur i in. 2008e, potwierdzenie 02.07.2010 r., AK, MiREK 2016), Skibówek - stanowisko 
prawdopodobnie tożsame ze stanowiskiem Mirka (1989, 2016): między Mraźnicą i Krzeptówkami (KotUla 1889-1890), z borów między Pardałówką i Olczyskim Potokiem (RADWAŃSKA-PARYSKA 1950, 1975 - potwierdzenie 01.07.2010 r., AK). Z Tatr podawany m. in. ze Starej Roboty w Dolinie Chochołowskiej (KotUla 1889-1890), z Toporowego Stawu Wyżniego (KotUla 1889-1890, Koczur i in. 2008e - ostatnie potwierdzenia 03.07.2010 r., AK; 29.08.2019 r., AK, AMO), Wielkiej Pańszczyckiej Młaki (PACYNA 1966; OBIDOwICZ 1975; KoczUR i in. 2008e - ostatnie potwierdzenia 07.07.2010 r. AK; 14.09.2019 r., AMO), z Małej Pańszczyckiej Młaki (PACYNa 1966; OBIDOwicz 1975; Koczur i in. 2008e - ostatnie potwierdzenia 16.07.2011 r. AK; 21.09.2019 r., AMO).

1. EG5046 Wyżnia Pańszczycka Młaka, T, R1, ok. 1309-1354 m, na torfowisku przejściowym, również w zaroślach kosodrzewiny, dość licznie, 07.07.2010 r., AK; 22.09.2019 r., AMO.

2. EG5057 Waksmundzka Młaka, T, R1, ok. 1366 m, na torfowisku przejściowym i w zaroślach kosodrzewiny na torfie, dość licznie, 07.07.2010 r., AK; 22.07.2019 r., AMO.

3. EG5057 Waksmundzka Rówień, T, R1, ok. 1408 m, na torfowisku wysokim i w zaroślach kosodrzewiny na torfie, 16.07.2011 r., AK; 22.09.2019 r., AMO.

4. DG5982, DG5993 Dolina Tomanowa, przy szlaku nad Smreczyński Staw, T, R1, 1160-1183 m, na torfowisku wysokim, w zaroślach kosodrzewiny na torfie i w podmokłej świerczynie górskiej, dość licznie, 02.08.2012 r., AK; 04.09.2019 r., AMO.

5. EG5045 Kotlinowy Wierch, T, R1, ok. 1283 m, ok. 1290 m n.p.m., płaty torfowiska przejściowego i wysokiego, licznie, 04.08.2012 r., AK; 19.08.2019 r., AMO.

6. EG6018 Żabie Oko, T, R2, ok. 1393 m, w zbiorowisku z dominacją Carex rostrata i w zaroślach kosodrzewiny na torfie, nielicznie, 05.08.2013 r., AK.

7. EG6018 Małe Morskie Oko, T, ok. 1396 m, płat torfowiska wysokiego, licznie, 05.08.2013 r., AK, 29.08.2020 r., AMO.

8. EG5082 poniżej Kotlinowego Stawku, T, R2, ok. 1677 m, na torfowisku przejściowym, nielicznie, 14.07.2014 r., AK, maksimum wysokościowe w Polsce.

9. DG5979 Dolina Kondratowa, T, ok. 1400 m, na torfowisku wysokim, pojedynczo, 11.09.2014 r., AK; 10.09.2019 r., AMO.

10. EG5015 Murzasichle Capówka, BP, ok. 961 m, na śródleśnym torfowisku przejściowym, licznie, 28.09.2019 r., AK, AMO.

11. EG5004 Wyskówki, BP, poza TPN, ok. 896 m, na kwaśnej młace, pojedynczo, 12.09.2019 r., AK;

12. EG5046 torfowisko na północ od Psiej Trawki, T, R1, ok. 1210 m, na torfowisku wysokim, bardzo licznie, 15.09.2019 r., AMO.

13. EG5046 Strzelecka Koliba, T, R1, ok. 1342 m, na torfowisku wysokim i w zaroślach kosodrzewiny na torfie, dość licznie, 19.09.2019 r., AMO.

14. EG5056 torfowisko na zachód od Pańszczyckiego Potoku, T, R1, ok. 1327 m, na torfowisku wysokim i w świerczynie na torfie, dość licznie, 21.09.2019 r, AMO.

15. EG5046 Butorów, T, R1, ok. 1280 m, na torfowisku wysokim, dość licznie, 16.10.2019 r., $\mathrm{AMO}, \mathrm{AZ}$.

16. EG5014 między Kiełbasówką a Wyskówkami, BP, ok. 950 m, na torfowisku wysokim, licznie, 05.08.2020 r., AMO.

\section{DYSKUSJA}

Na wstępie należy zaznaczyć, że badania florystyczne nie były głównym celem prowadzonych prac terenowych, dlatego informacje o braku potwierdzenia gatunku na stanowisku nie świadczą o jego wyginięciu. Pomimo że nie przeprowadzono dokładnych poszukiwań na wszystkich opisanych w przeszłości stanowiskach roślin torfowiskowych, natrafiono na 28 z nich. Jeszcze więcej, bo 36, to stanowiska wcześniej nie opisywane. Uwzględniając dane innych autorów z lat 2001-2020, w okresie tym potwierdzono stanowiska 30 gatunków oraz odkryto 37 nowych stanowisk roślin torfowiskowych (Tab. 1). 
Tabela 1. Liczba stanowisk gatunków torfowisk mszarnych w Tatrzańskim Parku Narodowym i jego sąsiedztwie

Table 1. Number of localities of peat bog species in Tatra National Park and its adjacent area

\begin{tabular}{lcccc}
\hline \hline Gatunek (Species) & $\begin{array}{c}\text { Liczba stanowisk } \\
\text { odnalezionych } \\
\text { w latach 1868-2020 } \\
\text { (Number of locali- } \\
\text { ties discovered in } \\
1868-2020)\end{array}$ & $\begin{array}{c}\text { Liczba stanowisk } \\
\text { potwierdzonych } \\
\text { w latach 2001-2020 } \\
\text { (Number of locali- } \\
\text { ties confirmed in } \\
2001-2020)\end{array}$ & $\begin{array}{c}\text { Liczba stanowisk } \\
\text { niepotwierdzonych } \\
\text { w latach 2001-2020 } \\
\text { (Number of locali- } \\
\text { ties not confirmed in } \\
2001-2020)\end{array}$ & $\begin{array}{c}\text { Liczba nowych } \\
\text { stanowisk odnalezi- } \\
\text { onych w latach } \\
\text { of localities discov- } \\
\text { ered in 2001-2020) }\end{array}$ \\
\hline Andromeda polifolia & 4 & 2 & - & 2 \\
Carex cespitosa & 3 & - & 1 & 2 \\
Carex limosa & 5 & 2 & 1 & 2 \\
Carex pauciflora & 18 & 7 & 5 & 6 \\
Comarum palustre & 4 & 2 & - & 2 \\
Drosera rotundifolia & 16 & 5 & 6 & 4 \\
Ledum palustre & 7 & 4 & 2 & 2 \\
Oxycoccus microcarpus & 6 & 1 & 2 & 16 \\
Oxycoccus palustris & 25 & 7 & 20 & 37 \\
\hline Razem (Total) & 88 & 30 & & 2 \\
\hline
\end{tabular}

Objaśnienia (Explanations): * - jedno stanowisko potwierdzają ZIĘBA i in. (2020) (one locality is confirmed by ZIĘBA et al. 2020).

Z omawianych dziewięciu gatunków siedem: Andromeda polifolia, Carex limosa, C. pauciflora, Comarum palustre, Drosera rotundifolia, Ledum palustre i Oxycoccus palustris zostało podanych z Tatr lub Bruzdy Podtatrzańskiej już w XIX w. Gatunki te odnaleziono na 17 stanowiskach. Obecnie potwierdzono $11 \mathrm{z}$ nich. W XIX stuleciu, przy okazji badań florystycznych, odnajdowano głównie pojedyncze, rozproszone stanowiska roślin torfowiskowych, większą liczbę gatunków odnotowano jedynie z Toporowego Stawu Wyżniego i Molkówki (Kotula 1889-1890).

W XX w. odnaleziono 35 nowych stanowisk omawianych gatunków, a także podano po raz pierwszy z tego regionu Carex cespitosa i Oxycoccus microcarpus. 13 lokalizacji opisanych w tym czasie nie zostało ostatnio potwierdzonych. Wśród doniesień nadal dominowały informacje o pojedynczych gatunkach na opisywanych stanowiskach. Większe ich zgrupowania stwierdzono, oprócz penetrowanych od XIX w. Wyżniego Stawu Toporowego i Molkówki, na Wielkiej Pańszczyckiej Młace (Pacyna 1966; OBIDowicz 1975) i Małej Pańszczyckiej Młace (Pacyna 1966; Obidowicz 1975) oraz w Dolinie Pięciu Stawów Polskich (BALCERKIEwicz 1984) w Tatrach, a także na Polanie Biały Potok (PięKoś-MirKOWA \& Mirek 1978; Pį̨Koś-Mirkowa 1982; Mirek \& PięKoś-Mirkowa 1989) na terenie Bruzdy Podtatrzańskiej.

Ze stanowisk obecnie niepotwierdzonych za nieistniejące można uznać tylko Krupówki. Według Szczegótowej mapy geologicznej Tatr (2016) torfy i namuły torfowe występują w ogólnie pojętym rejonie Krupówek między ulicą Seweryna Goszczyńskiego a ulicą hrabiego Władysława Zamoyskiego, na zachód od ulicy Józefa Piłsudskiego i na południe od ulicy Kornela Makuszyńskiego. Obecnie jest to teren zabudowany. Oprócz omawianych powyżej gatunków występowała tam również m.in. Calla palustris (KotUla 1889-1890; 
Tabela 2. Liczba stanowisk gatunków torfowisk mszarnych w Tatrach w obszarach Ramsar i poza nimi

Table 2. Number of localities of peat bog species at Ramsar Wetland Convention sites in the Tatra Mountains

\begin{tabular}{|c|c|c|c|c|c|c|c|c|}
\hline \multirow[t]{2}{*}{ Gatunek (Species) } & \multicolumn{2}{|c|}{$\begin{array}{c}\text { Liczba stanowisk } \\
\text { odnalezionych } \\
\text { w latach 1868-2020 } \\
\text { (Number of locali- } \\
\text { ties discovered in } \\
1868-2020)\end{array}$} & \multicolumn{2}{|c|}{$\begin{array}{l}\text { Liczba stanowisk } \\
\text { potwierdzonych } \\
\text { w latach 2001-2020 } \\
\text { (Number of locali- } \\
\text { ties confirmed in } \\
\text { 2001-2020) }\end{array}$} & \multicolumn{2}{|c|}{$\begin{array}{l}\text { Liczba stanowisk } \\
\text { niepotwierdzonych } \\
\text { w latach 2001-2020 } \\
\text { (Number of locali- } \\
\text { ties not confirmed in } \\
\text { 2001-2020) }\end{array}$} & \multicolumn{2}{|c|}{$\begin{array}{c}\text { Liczba nowych } \\
\text { stanowisk odnalezi- } \\
\text { onych w latach } \\
2001-2020 \text { (Number } \\
\text { of localities discov- } \\
\text { ered in 2001-2020) }\end{array}$} \\
\hline & $\mathrm{R}$ & NR & $\mathrm{R}$ & NR & $\mathrm{R}$ & NR & $\mathrm{R}$ & NR \\
\hline Andromeda polifolia & 4 & - & 2 & - & - & - & 2 & - \\
\hline Carex cespitosa & - & 1 & - & - & - & - & - & 1 \\
\hline Carex limosa & 2 & 1 & 1 & - & - & - & 1 & 1 \\
\hline Carex pauciflora & 11 & 5 & 5 & 1 & 4 & - & 6 & - \\
\hline Comarum palustre & 1 & - & 1 & - & - & - & - & - \\
\hline Drosera rotundifolia & 4 & 1 & 1 & - & 1 & 1 & 2 & - \\
\hline Ledum palustre & 3 & 2 & 1 & $1^{*}$ & 1 & 1 & 1 & - \\
\hline Oxycoccus microcarpus & 4 & - & 1 & - & 1 & - & 2 & - \\
\hline Oxycoccus palustris & 13 & 4 & 1 & 1 & - & 1 & 11 & 2 \\
\hline Razem (Total) & 42 & 14 & 13 & 3 & 7 & 3 & 25 & 4 \\
\hline
\end{tabular}

Objaśnienia (Explanations): R - obszar Ramsar (Ramsar area), NR - poza obszarem Ramsar (outside of Ramsar area); * - jedno stanowisko potwierdzają ZIĘBA i in. (2020) (one locality is confirmed by ZIĘBA et al. 2020).

KoczUR i in. 2008b). Wiele z niepotwierdzonych stanowisk (przede wszystkim dziewiętnastowiecznych) było niezbyt precyzyjnie zlokalizowanych, np. stanowisko Carex pauciflora z Ostrego Wierchu (KotUla 1889-1890). Jest prawdopodobne, że chodzi o jedno z torfowisk poniżej tego szczytu, np. Wyżnią Pańszczycką Młakę. Podobnie sprawa się przedstawia w przypadku stanowiska „u stóp Ornaku” (FrITZE \& ILSE 1870). Może chodzić o nieznaną lokalizację lub o torfowisko w Dolinie Tomanowej. Stanowisko Carex limosa określone jako „Bystre koło Zakopanego” (ReHMAN 1868) może być częścią Borów Jaszczurowskich. W XX i XXI w. turzyca bagienna nie została tam stwierdzona, lecz znajdujący się w tym miejscu kompleks torfowisk został przesuszony. Stanowisko określane jako Skibówki bądź Krzeptówki (Kotula 1889-1890) prawdopodobnie do XXI w. dotrwało w okrojonej postaci śródleśnego torfowiska położonego między Mrá́nicą a Krzeptówkami (MireK 2016). Na torfowisku na Molkówce została w latach siedemdziesiątych XX w. przeprowadzona melioracja, powtórzona w latach dziewięćdziesiątych. Obecnie rowy mają w sumie 500 m długości, 0,6 m szerokości i do $1 \mathrm{~m}$ głębokości (GLINIAK 2013). Ingerencja w stosunki wodne spowodowała zmiany w roślinności, pomimo to wiele gatunków torfowiskowych przetrwało (Comarum palustre, Drosera rotundifolia, Ledum palustre i Oxycoccus palustris). $\mathrm{Z}$ analizowanych obecnie nie odnaleziono Carex pauciflora, stwierdzono natomiast obecność Carex cespitosa.

Stanowiska omawianych gatunków torfowisk mszarnych w Tatrach znajdują się w większości w obrębie obszarów wodno - błotnych Ramsar wyznaczonych na terenie Tatrzańskiego Parku Narodowego (Tab. 2). Prezentowane wyniki badań znacząco poprawiają stan 
poznania tych cennych terenów. Natomiast nieliczne nowe lub potwierdzone po latach stanowiska odnalezione poza tymi obszarami mogą sugerować o jakie jeszcze tereny warto byłoby w przyszłości je rozszerzyć.

W dyskusji pominięto Listera cordata, ponieważ wykazuje szersze spektrum ekologiczne w porównaniu z pozostałymi gatunkami.

Stopień poznania torfowisk tatrzańskich, a co za tym idzie rozmieszczenia gatunków torfowiskowych na terenie Tatrzańskiego Parku Narodowego i terenów przyległych jest bardzo zróżnicowany. Część stanowisk podanych przez KotUlę (1889-1890) obserwowana jest od około 130 lat i wielokrotnie potwierdzana. Inne do niedawna pozostawały nieznane. Dopiero obecnie doczekały się szczegółowych badań botanicznych liczne torfowiska w dolinie Suchej Wody Gąsienicowej (Ryc. 1) (od dawna eksplorowane naukowo były Toporowe Stawy i Pańszczyckie Młaki w tym rejonie), niewielkie torfowisko w dolinie Kondratowej (Ryc. 2), torfowiska w Dolinie Tomanowej (Ryc. 3) i Dolinie Rybiego Potoku. Odnalezienie nowych stanowisk rzadkich roślin torfowiskowych związane jest nie tyle z sukcesją, czy pojawianiem się nowych siedlisk, co z nadal niepełnym rozpoznaniem torfowisk tatrzańskich. Przyczyniło się do tego ich duże rozproszenie i niewielkie rozmiary. Uwaga większości badaczy skierowana była głównie na siedliska i gatunki górskie, przede wszystkim stanowiące ewenement w skali kraju rośliny wysokogórskie. Siedliska torfowiskowe i rosnące tu gatunki stanowiły temat marginalny.

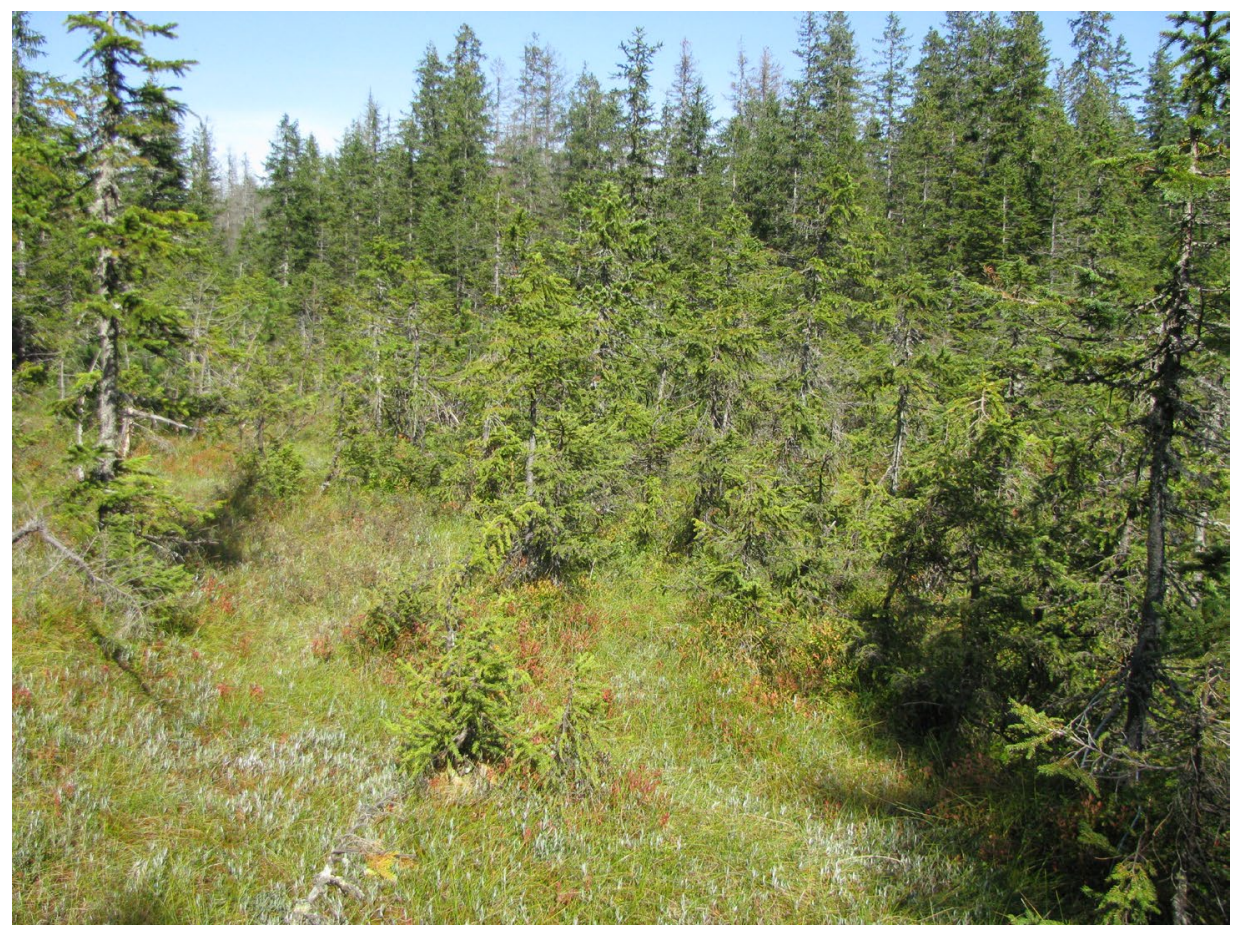

Ryc. 1. Torfowisko na zachód od Pańszczyckiego Potoku (21.09.2019 r., fot. A.M. Ociepa)

Fig. 1. Peat bog west of Pańszczycki Stream (21 September 2019; photo by A. M. Ociepa) 


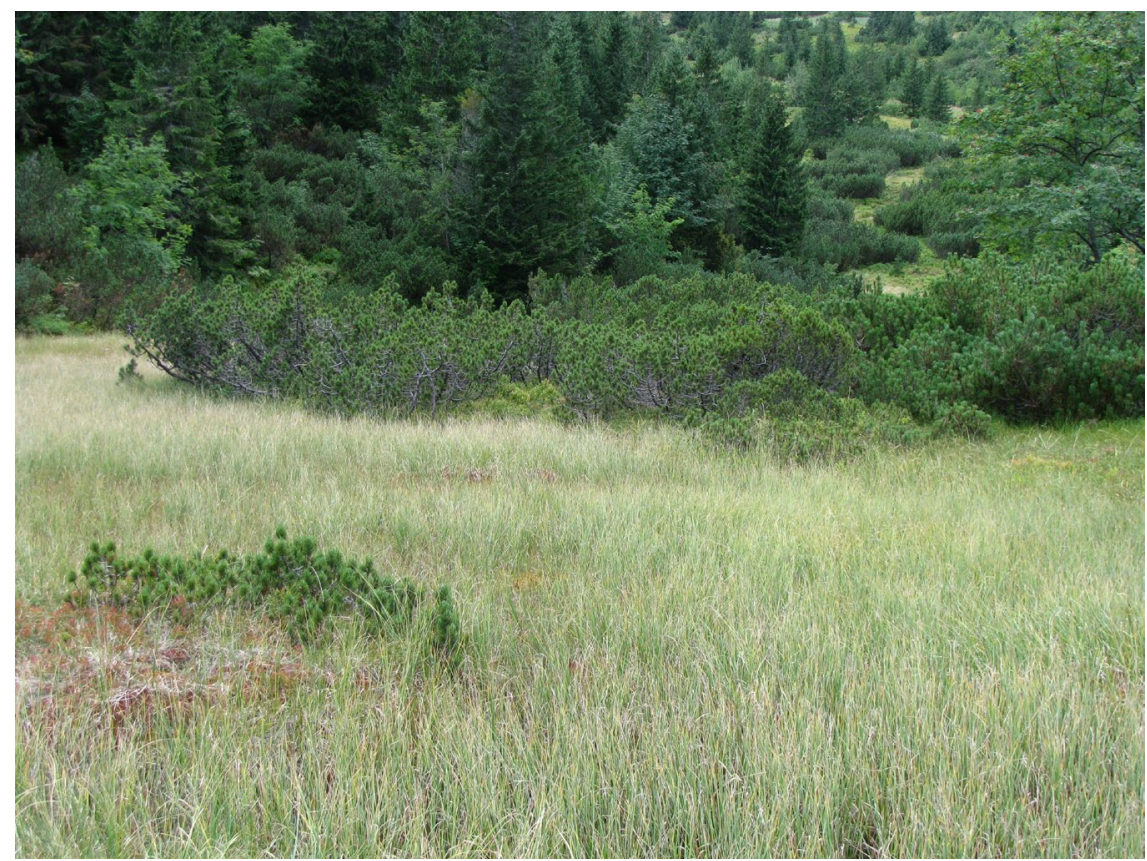

Ryc. 2. Torfowisko w Dolinie Kondratowej (10.09.2019 r., fot. A. M. Ociepa)

Fig. 2. Peat bog in the Kondratowa Valley (10 September 2019; photo by A. M. Ociepa)

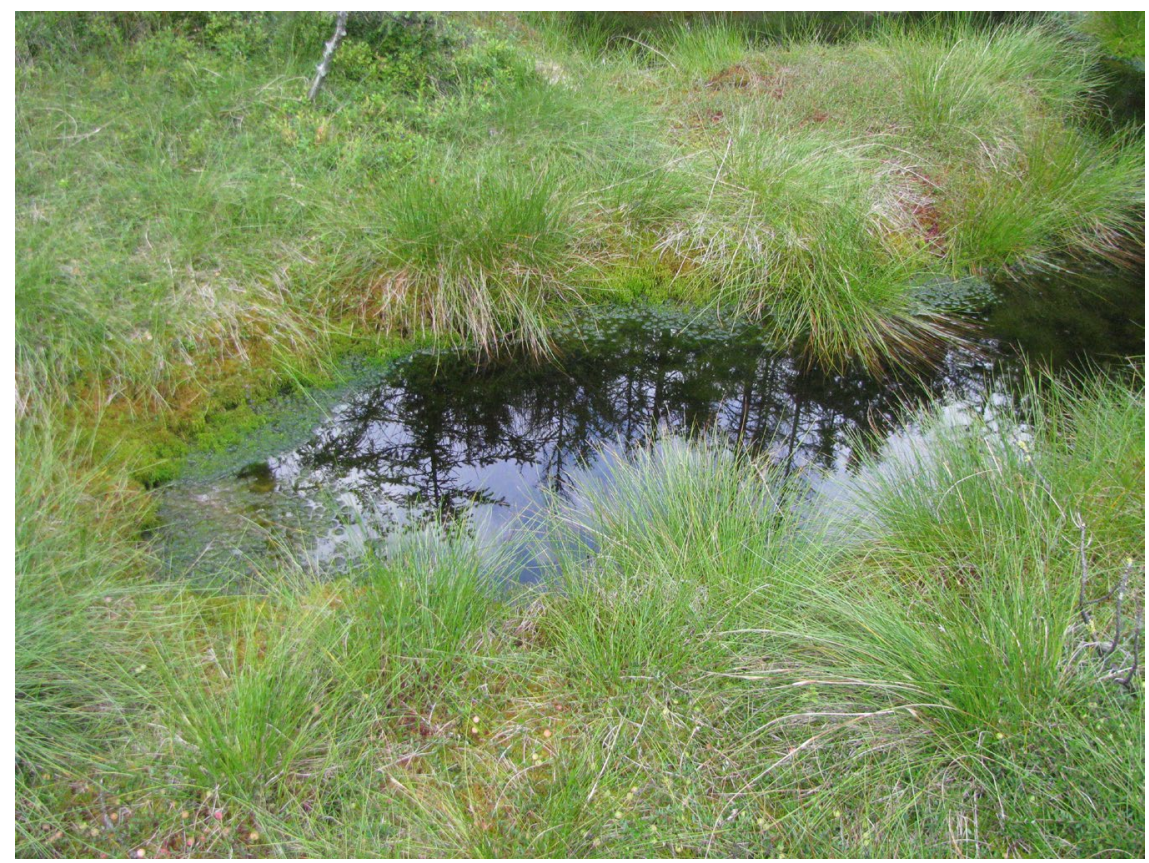

Ryc. 3. Torfowisko w Dolinie Tomanowej (01.09.2019 r., fot. A. M. Ociepa)

Fig. 3. Peat bog in the Tomanowa Valley (1 September 2019; photo by A. M. Ociepa) 
Podziękowania. Autorzy dziękują mgr. inż. Pawłowi Kauzalowi z Tatrzańskiego Parku Narodowego za udostępnienie danych dotyczących potwierdzenia występowania Carex limosa na Wielkiej Pańszczyckiej Młace, dr. Bogusławowi Binkiewiczowi z Instytutu Botaniki Uniwersytetu Jagiellońskiego za udostępnienie danych dotyczących potwierdzenia występowania Carex pauciflora w Dolinie Pięciu Stawów Polskich.

Badania częściowo sfinansowano ze środków Funduszu Leśnego Państwowego Gospodarstwa Leśnego Lasy Państwowe przekazanych Tatrzańskiemu Parkowi Narodowemu w 2019 i 2020 r.

\section{LITERATURA}

Balcerkiewicz S. 1984. Roślinność wysokogórska Doliny Pięciu Stawów Polskich w Tatrach i jej przemiany antropogeniczne. - Wydawnictwo Naukowe Uniwersytetu A. Mickiewicza, Seria Biologia 25: $1-191$.

BALON J., JodŁowski M. \& KRĄż P. 2015. Mikroregiony fizycznogeograficzne Tatr. - W: K. DĄBRowsKA \& M. GuzıK (red.), Atlas Tatr - Przyroda nieożywiona, Zakopane, Tatrzański Park Narodowy, plansza I.4.

Binkiewicz B., Pięta M. \& Pięta G. 2017. Rozmieszczenie, zasoby oraz zagrożenia Epipogium aphyllum i Listera cordata (Orchidaceae) w lasach Tatrzańskiego Parku Narodowego. - Fragmenta Floristica et Geobotanica Polonica 24(1): 85-98.

Derkacz M. 2006. Jeziora i torfowiska w Dolinie Suchej Wody w Tatrach i ich geneza wytopiskowa. - Przegląd Geologiczny 54(1): 73-75.

FRITZE R. \& ILSE H. 1870. Karpaten-Reise. - Verhandlungen der kaiserlich-königlichen zoologisch-botanischen Gesellschaft in Wien 20: 467-526.

GLINIAK M. 2013. Ocena zagrożenia środowiska przyrodniczego i logistyki ruchu turystycznego w otulinie Tatrzańskiego Parku Narodowego na przykładzie Polany Molkówka. - Logistyka 4: 138-142.

HaJeK M. 1999. The Valeriano simplicifoliae-Caricetum flavae association in the Podhale region (Western Carpathians, Poland): notes on syntaxonomical and successional relationships. - Fragmenta Floristica et Geobotanica 44(2): 389-400.

JAKUBOWSKA-GABARA J. \& KUCHARSKI L. 1999. Ginące i zagrożone gatunki flory naczyniowej zbiorowisk naturalnych i półnaturalnych Polski Środkowej. - Fragmenta Floristica et Geobotanica Series Polonica 6: $55-74$.

Jiménez-Mejías P., Hilpold A., Frajman B., Puşcaş M., Koopman J., Mesterházy A., Grulich V., Lye K. A. \& Martín-Bravo S. 2014. Carex cespitosa: reappraisal of its distribution in Europe. - Willdenowia 44: 327-343.

KaŹMIERCZAKOwa R., ZARZYCKI K. \& MireK Z. 2014. Polska czerwona księga roślin. Paprotniki i rośliny kwiatowe. Wyd. 3. s. 895. Instytut Ochrony Przyrody, Polska Akademia Nauk, Kraków.

Kaźmierczakowa R., Bloch-OrŁowska J., Celka Z., Cwener A., Dajdok Z., Michalska-Hejduk D., Pawlikowski P., Szcześninia E. \& Ziarnek K. 2016. Polska czerwona lista paprotników i roślin kwiatowych. s. 44. Instytut Ochrony Przyrody Polskiej Akademii Nauk, Kraków.

KAUZAL P. \& ZiĘBA A. 2018. Ramsar w Tatrach. - Tatry TPN 64: 11.

Koczur A. \& KorZeniaK J. 2008. Żurawina drobnoowockowa (Ż. drobnolistkowa) Oxycoccus microcarpus Turcz. ex Rupr. - W: Z. MireK \& H. PięKoś-Mirkowa (red.), Czerwona księga Karpat Polskich. Rośliny naczyniowe, s. 172-174. Instytut Botaniki im. W. Szafera PAN, Kraków.

Koczur A., Piękoś-Mirkowa H., Mitka J. \& Szary A. 2008a. Bagno zwyczajne Ledum palustre L. - W: Z. MiReK \& H. PięKoś-Mirkowa (red.), Czerwona księga Karpat Polskich. Rośliny naczyniowe, s. 169-171. Instytut Botaniki im. W. Szafera PAN, Kraków. 
Koczur A., Mirek Z. \& PięKoś-Mirkowa H. 2008b. Czermień błotna Calla palustris L. - W: Z. Mirek \& H. PięKoś-MiRkowa (red.), Czerwona księga Karpat Polskich. Rośliny naczyniowe, s. 556-558. Instytut Botaniki im. W. Szafera PAN, Kraków.

Koczur A., Mirek Z., Oklejewicz K. \& PięKoś-Mirkowa H. 2008c. Turzyca bagienna Carex limosa L.

- W: Z. MiReK \& H. PięKoś-Mirkowa (red.), Czerwona księga Karpat Polskich. Rośliny naczyniowe, s. 516-517. Instytut Botaniki im. W. Szafera PAN, Kraków.

Koczur A., Mirek Z., MitKa J. \& Szary A. 2008d. Turzyca skąpokwiatowa Carex pauciflora L. - W: Z. Mirek \& H. PięKoś-Mirkowa (red.), Czerwona księga Karpat Polskich. Rośliny naczyniowe, s. 520-522. Instytut Botaniki im. W. Szafera PAN, Kraków.

Koczur A., Mitka J., Oklejewicz K. \& PięKoś-Mirkowa H. 2008e. Żurawina błotna Oxycoccus palustris Pers. - W: Z. Mirek \& H. PięKoś-Mirkowa (red.), Czerwona księga Karpat Polskich. Rośliny naczyniowe, s. 175-177. Instytut Botaniki im. W. Szafera PAN, Kraków.

Koczur A. 2013. Nerecznica grzebieniasta Dryopteris cristata w Bieszczadach - rozmieszczenie i uwarunkowania siedliskowe. - Roczniki Bieszczadzkie 21: 57-63.

KOMSTA Ł. 2016. Rewizja matematyczna siatki geobotanicznej ATPOL - propozycja algorytmów konwersji współrzędnych. - Agronomy Science 71(1): 31-37.

Korzeniak J., Koczur A. \& Piękoś-Mirkowa H. 2008a. Modrzewnica pospolita (M. północna) Andromeda polifolia L. - W: Z. Mirek \& H. PięKoś-Mirkowa (red.), Czerwona księga Karpat Polskich. Rośliny naczyniowe, s. 166-168. Instytut Botaniki im. W. Szafera PAN, Kraków.

Korzeniak J., Koczur A. \& PięKoś-Mirkowa H. 2008b. Siedmiopalecznik błotny Comarum palustre L. - W: Z. Mirek \& H. Pię́oś-Mirkowa (red.), Czerwona księga Karpat Polskich. Rośliny naczyniowe, s. 200-201. Instytut Botaniki im. W. Szafera PAN, Kraków.

KотUla B. 1889-1890. Rozmieszczenie roślin naczyniowych w Tatrach. s. 512. Nakładem Wydziału Matematyczno-Przyrodniczego Akademii Umiejętności, Kraków.

ŁAJCZAK A. 2014. Rola podłoża w rozwoju torfowisk w polskich Karpatach. - Studia Limnologica et Telmatologica 8(1): 19-36.

Matuszkiewicz W. 2008. Przewodnik do oznaczania zbiorowisk roślinnych Polski. s. 538. Wydawnictwo Naukowe PWN, Warszawa.

Mirek Z. 1989. Materiały do flory Tatrzańskiego Parku Narodowego i północnego Podtatrza. - Fragmenta Floristica et Geobotanica 34(3-4): 283-298.

MiReK Z. 2016. Rośliny naczyniowe Rowu Podtatrzańskiego. Flora i atlas rozmieszczenia. s. 314. Instytut Botaniki im. W. Szafera Polskiej Akademii Nauk, Kraków.

Mirek Z. \& PięKoś-Mirkowa H. 1989. Polana Biały Potok, obiekt przyrodniczy godny szczególnej ochrony. - Chrońmy Przyrodę Ojczystą 45(5-6): 71-73.

Mirek Z. \& Pięroś-Mirkowa H. 1995. Szata roślinna Tatr Polskich. - Polish Botanical Studies, Guidebook Series 12: 73-150.

Mirek Z. \& Pię́oś-Mirkowa H. 2008. Czerwona księga Karpat Polskich. Rośliny naczyniowe. s. 615. Instytut Botaniki im. W. Szafera PAN, Kraków.

Mirek Z., Pię́oś-Mirkowa H. \& Czerny M. 2013a. Operat ochrony roślin i grzybów (rośliny naczyniowe). s. 136. Mskr. do projektu Planu Ochrony TPN. KRAMEKO sp. z o. o., Kraków.

Mirek Z., Binkiewicz B., CZerny M. \& Bielecki M. 2013b. Operat ochrony ekosystemów nieleśnych. s. 157. Mskr. do projektu Planu Ochrony TPN. KRAMEKO sp. z o. o., Kraków.

Mirek Z., PięKoś-Mirkowa H., ZająC A. \& ZająC M. 2002. Flowering plants and pteridophytes of Poland. A checklist. - W: Z. MireK (red.), Biodiversity of Poland. 1, s. 442. W. Szafer Institute of Botany, Polish Academy of Sciences, Kraków. 
NowaK A., NowaK S. \& SpaŁEK K. 2008. Red list of vascular plants of Opole province - 2008. - Nature Journal 41: 141-158.

OBIDowicz A. 1975. Enstehung und Alter einiger Moore im nördlichen Teil der Hohen Tatra. - Fragmenta Floristica et Geobotanica 21(3): 281-323.

PaCYNA A. 1966. Nowe stanowisko Andromeda polifolia L. i Oxycoccus microcarpus Turcz. w Tatrach. - Fragmenta Floristica et Geobotanica 12(1): 13-14.

Parusel J. B. \& Urbisz A. (red.). 2012. Czerwona lista roślin naczyniowych województwa śląskiego. - Raporty Opinie 6(2): 105-177.

Pawłowski B. 1956. Flora Tatr. 1. s. 672. Państwowe Wydawnictwo Naukowe, Warszawa.

PawŁowski B., SokoŁowski M. \& Wallisch K. 1928. Zespoły roślinne w Tatrach. Cz. VII. Zespoły roślinne i flora doliny Morskiego Oka. - Bulletin International De l'Académie Polonaise Des Sciences et Des Lettres Classe Des Sciences Mathématiques et Naturelles, Série B: Sciences Naturelles 1927, Suppl. II: 205-272.

PięKoś H. 1968. Rozmieszczenie roślin regla dolnego i górnego na Sarniej Skale, Krokwi i Łysankach w Tatrach. - Fragmenta Floristica et Geobotanica 14(3): 317-386.

PięKOŚ-Mirkowa H. 1982. Rzadkie taksony roślin naczyniowych na terenie Tatrzańskiego Parku Narodowego - ich zagrożenie ze strony turystyki oraz problemy ochrony. - Studia Naturae, Seria A 22: 79-132.

Pį̨KOŚ-Mirkowa H. \& MireK Z. 1978. O rzadkich lub dotychczas z obszaru Tatr nieznanych gatunkach roślin naczyniowych. - Fragmenta Floristica et Geobotanica 24(3): 363-368.

Raciborski M. 1911. Rośliny polskie. Nr 801-900. Rośliny Tatr. Flora Polonica Exiccata. Flora Tatrorum. - Kosmos 36: 1049-1062.

RADWAŃSKA-PARYSKa Z. 1950. Tatrzańskie notatki florystyczne. - Acta Societatis Botanicorum Poloniae 20: $557-576$.

RADWAŃSKA-PARYSKA Z. 1975. Materiały do rozmieszczenia dendroflory Tatr i Podtatrza. - W: S. MYCZKOWSKI (red.), Native trees of the Tatra Mountains. 2. - Studia Ośrodka Dokumentacji Fizjograficznej PAN 4: 13-77.

RAMSAR Sites Information Service. https://rsis.ramsar.org/ris/2341 (dostęp: 8.06.2020).

Rehman A. 1868. Botanische Fragmente aus Galizien. - Verhandlungen der Zoologisch-Botanischen Gesellschaft in Wien 18: 479-506.

RoZPORZĄDZENIE Ministra Środowiska z dnia 9 października 2014 r. w sprawie ochrony gatunkowej roślin (Dz. U. 2014 r., poz. 1409).

Szafer W., PawŁowski B. \& Kulczyński S. 1927. Die Pflanzenassoziationen des TatraGebirges. III Teil: Die Pflanzenassoziationen des KościeliskaTales. - Bulletin International De l'Académie Polonaise Des Sciences et Des Lettres Classe Des Sciences Mathématiques et Naturelles. Série B: Sciences Naturelles 1926, Suppl. II: 13-78.

SzczegóŁowa Mapa Geologiczna Tatr w SKali 1:10 000. 2016. Państwowy Instytut Geologiczny - Państwowy Instytut Badawczy, Warszawa.

Solon J., Borzyszkowski J., BidŁasik M., Richling A., Badora K., Balon J., BrzezińsKa-Wójcik T., Chabudziński Ł., Dobrowolski R., Grzegorczyk I., JodŁowski M., Kistowski M., Kot R., Krąż P., Lechnio J., Macias A., Majchrowska A., Malinowska E., Migoń P., Myga-Piątek U., Nita J., Papińska E., Rodzik J., Strzyż M., TerpiŁowski S. \& Ziaja W. 2018. Physico-geographical mesoregions of Poland: Verification and adjustment of boundaries on the basis of contemporary spatial data. - Geographia Polonica 91(2): 143-170.

STECKI K. 1922. Linnaea borealis L. w Polsce oraz nowe stanowiska kilkunastu roślin tatrzańskich. - Kosmos 47: 125-140. 
ZAJĄC A. 1978. Założenia metodyczne „Atlasu rozmieszczenia roślin naczyniowych w Polsce”. - Wiadomości Botaniczne 22(3): 145-155.

ZAJĄC A. \& ZAJĄC M. 2001. Atlas rozmieszczenia roślin naczyniowych w Polsce. s. xii +716 . Pracownia Chorologii Komputerowej Instytutu Botaniki Uniwersytetu Jagiellońskiego, Kraków.

Zięba, A., Wróbel, S., Kauzal, P., Delimat A., Ociepa A. M., KozaK M., KozŁowska-KozaK K., Czortek P., Baran J., Bryniarski, G., Gąsienica-Roj, W., Tylka, W., Zięba F., Nejfeld P., Kawulak M. \& Widlak M. 2020. Przyczynki do flory Tatrzańskiego Parku Narodowego. - Fragmenta Floristica et Geobotanica Polonica 27(2): 379-394.

\section{SUMMARY}

Peat bogs occupy small areas in Tatra National Park (TNP) but they are important habitats for rare and threatened species of flowering plants. In 2018 the peat bogs of Tatra National Park were placed on the list of wetlands of international importance (RAMSAR CONVENTION ON WETLANDS) (Tab. 2).

We present new localities of species that are rare and threatened according to the Polish Red Data Book of Plants (KaźmierCZaKowa et al. 2014), the Red Data Book of the Polish Carpathians - Vascular Plants (MireK \& PięKoś-Mirkowa 2008) and the Polish red list of pteridophytes and flowering plants (KAŹMIERCZAKOWA $\mathrm{i}$ in. 2016), and describe one new species for TNP. The paper presents 40 new localities (Figs 1-3) of 10 peat bog species in TNP and the adjoining area (e.g. Andromeda polifolia, Carex cespitosa, C. limosa, C. pauciflora, Comarum palustre, Drosera rotundifolia, Ledum palustre, Listera cordata, Oxycoccus microcarpus, $O$. palustris) The data were collected during field studies carried out in 2010-2020. The locality descriptions include the ATPOL square code, concise topographic and habitat characteristics, and the date and author of the observation.

The localities of peat bog species in the Tatras are stable. Some of them have been observed for roughly the last 130 years, especially those in the interior of TNP (Tab. 1). Most of the localities that are no longer extant were at sites now within urban areas (Zakopane and adjacent municipalities) outside of TNP. New sites of rare peat bog species were recorded, due to better recognition of Tatra peat bogs rather than transformation of sites or the emergence of new suitable localities for these plants.

Wptynęto: 29.02.2020 r.; przyjęto do druku: 26.11.2020 r. 